\title{
KEWENANGAN OTORITAS JASA KEUANGAN MENGENAI PERLINDUNGAN HUKUM BAGI INVESTOR TERHADAP TINDAKAN TIPPEE YANG MELAKUKAN INSIDER TRADING DALAM PERDAGANGAN SAHAM
}

\author{
Oleh: \\ Made Dwi Juliana ${ }^{1}$
}

\section{ABSTRACT}

One type of a criminal in the capital market is the practice of insider trading. Insider trading is an act that involves a group of insider in the capital market who deliberately exploit information that has not been released to investors with the advantages. In insider trading there are two actors such as party directly as an insider who works in the company or indirect as tippee party who obtain confidential information from an insider. Tippee is the party who receives confidential information from an insider either passively or actively against the law or not against the law for personal gain in the stock trading. This is very detrimental to the investors in the stock trading. Because of that if needs the protection for investors against the actions of the Tippee. This study discusses two (2) problem first about the subject matter of the action form Tippee in insider trading to the stock at Indonesia and the second about OJK authority on legal protection for investors in case of insider trading by the Tippee in capital market activities. This research is a normative law. The Method approach is the approach of legislation, conceptual approach and comparative approach. Legal materials used are primary and secondary legal materials. Mechanical collection of legal materials is through the study of literature that further uses analysis techniques that description techniques and interpretation. The results shows that this form of action Tippee can be done actively and passively. Actively to perform an unlawful act such as stealing information. In is not trying to fight the law, but to obtain inside information and legal safeguards for investors to act with regard to insider trading Tippee do give legal certainty through legislation and legal certainty by the OJK through law enforcement.

Key words: Insider, Tippee, Investors, Insider Trading, Legal Protection.

\section{PENDAHULUAN}

\subsection{Latar Belakang}

Pasar modal inilah tempat bertemunya penjual dan pembeli yang dalam hal ini adalah calon investor dengan perusahaan dan investor dengan investor. Dengan adanya pasar modal inilah sebagai tempat investor

Mahasiswa Magister Ilmu Hukum Universitas Udayana, Denpasar, Bali. Alamat Jln. Sumandang II No. 11 Br. Kapal Batubulan, email: madedwijuliana@ ymail.com. untuk membeli saham seingga dapat memililiki sebagian dari suatu perusahaan. Investor yang akan membeli suatu saham perusahaan dalam kegiatan pasar modal akan menjadi aman jika ada suatu keterbukaan dalam kegiatan pasar modal.

Investor merupakan istilah yang ada dalam kegiatan pasar modal. Investor tersebut bisa dikatakan sebagai pembeli atau penjual saham yang maksudnya disini adalah investor tersebut sebagai pembeli atas saham perusahaan yang perusahaan tersebut 
melakukan pengumuman kepada masyarakat bahwa perusahaan memerlukan dana untuk meningkatkan mutu perusahaan. Perusahaan yang ingin memperoleh dana tersebut harus

membuka perdagangan saham sehingga dengan adanya pengumuman perdagangan saham maka calon pembeli atau investor akan datang untuk melakukan pembelian saham atas perusahaan tersebut. Adanya pembelian saham oleh investor ini merupakan kegiatan awal dalam perdangangan saham yang dalam hal ini merupakan kegiatan dalam pasar perdana. Setelah membeli saham maka investor akan ikut memiliki perusahaan tersebut karena sudah membeli saham dari perusahaan tersebut. Investor yang sudah membeli saham tersebut dalam melakukan perdagangan saham dengan menjual saham tersebut kepada investor yang lain. Adanya penjualan saham oleh investor kepada investor yang lain merupakan kegiatan perdagangan saham setelah pasar perdana yang dalam hal ini kegiatan tersebut dilakukan dalam pasar sekunder. Dalam pasar sekunder perdana investor hanya dapat membeli saham sedangkan dalam pasar sekunder investor dapat membeli saham dan menjual saham yang telah dimiliki kepada investor lain.

Dalam kegiatan pasar modal adanya suatu keterbukaan yang dalam dalam hal ini keterbukaan informasi maka akan dapat menciptakan pasar modal yang efisien. Keterbukaan informasi merupakan jiwa dari pasar modal karena dengan keterbukaan informasi inilah pasar modal akan dipercaya sebagai tempat atau wadah untuk adanya perdagangan saham yang dalam hal ini investor akan dapat melakukan perdagangan saham.
Adanya keterbukaan informasi akan memudahkan investor untuk melakukan perdagangan saham karena dengan keterbukaan informasi inilah investor akan memperoleh informasi perusahaan secara benar, jelas dan tepat waktu serta secara bersama sesuai keadaan $^{2}$ sehingga investor yang memperoleh informasi tersebut akan dapat menganalisis dari informasi tersebut sehingga investor dapat melakukan perdagangan saham baik itu membeli atau menjual saham.

Keterbukaan informasi inilah akan membuat perdagangan saham semakin efisien sehingga akan semakin diminati oleh investor yang ingin melakukan perdagangan saham dalam kegiatan pasar modal. Namun apabila suatu keterbukaan informasi sudah tidak ada dalam pasar modal maka tentu saja pasar modal akan kurang diminati oleh investor-investor dan tentu saja akan menyebabkan kegiatan pasar modal tidak akan berjalan secara efisien serta dapat menciptakan perdagangan saham yang tidak fair. Salah satu kejahatan dalam perdagangan tidak adil adalah insider trading.

Insider trading ialah kegiatan perdagangan saham yang dilakukan oleh pihak tergolong orang dalam yang memiliki informasi rahasia perusahaan yang dalam hal ini orang dalam tersebut dapat melakukan perdagangan dengan informasi tersebut untuk kepentingan pribadi atau memberikan informasi tersebut kepada pihak lain.

Dalam perdagangan saham terkadang dilakukan oleh orang luar tetapi mem-

M. Irsan Nasarudin, 2004, Aspek Hukum Pasar Modal Indonesia, Jakarta, Kencana, hlm.230. 
peroleh informasi dari insider yang disebut tippee $^{3}$. Tippee yang memperoleh informasi dari orang dalam tersebut maka akan segera melakukan perdangan saham dan investor yang tidak mengetahui informasi tersebut maka akan sangat dirugikan terlebih lagi investor yang ingin melakukan perdangan saham yang akan menjual atau membeli saham ${ }^{4}$ harus menunggu pada saat perusahaan ingin membuka perdagangan saham karena pada saat itulah informasi mengenai perusahaan tersebut akan diberikan sehingga setelah informasi diperoleh maka investor akan menganalisis dan memutuskan untuk melakukan perdagangan saham atau tidak melakukan perdagangan saham. Selain itu tippee yang memperoleh informasi perusahaan sebelum adanya pemberitahuan oleh perusahaan yang ingin melakukan perdangan saham maka akan dimanfaatkan tippee untuk duluan melakukan pembelian saham dengan harga yang murah yang kemudian akan menjualnya dengan harga yang lebih tinggi kepada investor lain. Oleh karena itu dengan adanya tindakan dari tippee ini maka akan sangat merugikan investor karena investor yang tidak mengetahui bahwa informasi yang seharusnya diperoleh secara bersamaan pada waktu perusahaan membuka perdagangan saham ternyata sudah diketahui oleh pihak-pihak yang dalam hal ini adalah tippee sehingga akan dapat dimanfaatkan oleh tippee untuk keuntungan pribadi dalam melakukan perdagangan saham. Maka dari itu diperlukan perlindungan hukum terhadap

Tandi, 2013, Analisis Terhadap Larangan Praktik Insider Trading di Pasar Modal, Vol.II. hlm.2.

4 Jusuf A., Pasar Modal Indonesia, P.T Alumni, Bandung, hlm.54-55. investor karena adanya investasi inilah dapat memajukan perekonomian negara ${ }^{5}$ dan akan menciptakan keadilan untuk investor dalam memperoleh kedudukan yang sama ${ }^{6}$ dalam melakukan perdagangan saham.

\subsection{Rumusan Masalah}

1. Bagaimanakah tindakan tippee terhadap insider trading dalam perdagangan saham di Indonesia?

2. Bagaimanakah kewenangan OJK terhadap perlindungan hukum bagi investor terhadap insider trading oleh tippee di pasar modal?

\subsection{Tujuan Penelitian}

Tujuan penelitian tersebut yaitu:

1. Mengetahui tindakan tippee terhadap insider trading dalam perdagangan saham di Indonesia.

2. Mengetahui kewenangan OJK terhadap perlindungan hukum bagi investor dalam insider trading oleh tippee di pasar modal.

\section{METODE PENELITIAN}

Dalam penelitian ini digunakan penelitian normatif dengan mengkaji melalui peraturan perundang-undangan yang tertulis dalam peraturan perundang-undangan ${ }^{7}$. Jenis pendekatan yang digunakan yaitu pendekatan perundang-undangan, kasus, konseptual dan perbandingan. Pendekatan perundang-

Hendrik Budi Untung, 2010, Hukum Investasi, Sinar Grafika, Jakarta, hlm.15.

H.L.A Hart, 2013, Konsep hukum,cet, V terjemahan M. Khozim, Nusa Media, Bandung, hlm.246. 
undangan yaitu dilakukan dengan membaca dan menganalisis peraturan perundang-undangan yang sesuai permasalahan. Pendekatan kasus dilihat dalam kasus yang sesuai dengan permasalahan. Pendekatan konseptual dilihat pada doktrin ilmu hukum untuk membangun suatu argumentasi hukum untuk menyelesaikan masalah $^{8}$. Pendekatan perbandingannya adalah Indonesia dengan Amerika Serikat terhadap konsep hukum yang berbeda. Dalam penelitian hukum normatif tersebut digunakan untuk menganalisis permasalahan yang ada. ${ }^{9}$

Bahan hukum dalam penulisan ini adalah bahan hukum primer ialah UU No 8 Tahun 1995 Tentang Pasar Modal, UU No 21 tahun 2011 Tentang OJK dan bahan hukum sekunder ialah buku dan jurnal hukum. Kemudian setelah pengumpulan bahan hukum dicatat secara berurutan dari data hukum yang didapat dari kepustakaan. Setelah itu dilakukan pemaparan melalui teknik deskriptif analisis dengan sistematis, dan interpretasi. Kemudian bahan diseleksi dan dianalisis dengan teknik deskripsi ${ }^{10}$ dengan tujuan untuk menguraikan hukum atau non hukum ${ }^{11}$. Selanjutnya menggunakan teknik

H. Amiruddin dan Zainal Aaikin, 2008, Pengantar Metode Penelitian Hukum, PT. Raja Grafindo Persada, Jakarta, hlm.118

8 Peter M. Marzuki, 2005, Penelitian Hukum, Prenada Media, Jakarta, hlm.93.

9 Johnny Ibrahim, 2005, Teori \& Metodologi Penelitian Hukum Normatif, Bayumedia Publishing, Surabaya, hlm. 300 .

10 M. Syamsudin, 2007, Operasionalisasi Penelitian Hukum, PT. Raja Grafindo Persada, Jakarta, hlm.133.

11 S. Mamudji, 2005, Metode Penelitian Dan Penulisan Hukum, Fakultas Hukum Universitas Indonesia, Jakarta, hlm.4. interpretasi dengan menggunakan penafsiran gramatika, sistimatis, dan historis. ${ }^{12}$

\section{HASIL DAN PEMBAHASAN}

\subsection{Tindakan Tippee Dalam Insider Trading}

Insider trading ialah kegiatan perdagangan saham dilakukan oleh orang dalam yang memiliki informasi rahasia perusahaan yang dalam hal ini orang dalam tersebut dapat melakukan perdagangan dengan informasi tersebut untuk kepentingan pribadi atau memberikan informasi tersebut kepada pihak lain. Oleh karena itu maka akan ada perdagangan yang tidak adil $^{13}$ terutama apabila dilakukan oleh pihak luar tetapi mendapatkan informasi dari orang dalam yang disebut tippee. Oleh karena itu ini berarti tippee merupakan pelaku insider trading, namun tidak dalam kategori insider karena tippee ialah pihak luar yang mendapatkan informasi dari insider.

Tindakan yang dikategorikan sebagai tindakan tippee dapat dilakukan dengan pasif dan aktif. Tindakan aktif ialah tippee memperoleh informasi insider dengan perbuatan melawan hukum seperti mengancam dan mencuri informasi orang dalam tersebut. Secara pasif ialah tippee memperoleh informasi insider dengan tidak melawan hukum bahwa orang dalam dengan sadar memberikan informasi rahasia perusahaan kepada tippee untuk melakukan perdagangan saham.

12 Pedoman Penulisan Usulan Penelitian Tesis Dan Penulisan Tesis, 2013, Program Studi Magister Ilmu Hukum, hlm.35.

13 Tavinayati dan Yulia Q., 2009, Hukum Pasar Modal Di Indonesia, Sinar Grafika, Jakarta, hlm.78-79. 


\subsection{Kewenangan OJK Mengenai Perlindungan Hukum Bagi Investor Terhadap Tindakan Tippee Dalam Insider Trading}

Perlindungan hukum untuk investor mengenai tindakan tippee dalam insider trading ada 2 (dua) ialah dengan kepastian hukumdalamperaturanPerundang-undangan dan dengan penegakan hukumnya ${ }^{14}$. Kepastian hukum dalam peraturan perundang-undangan akan memberikan perlindungan kepada investor mendapatkan informasi lengkap, akurat dan benar dalam melakukan perdagangan saham. Bentuk tindakan aktif sudah diatur dalam pasal 97 UUPM Sedangkan tindakan pasif belum diatur dalam UUPM.

Dalam hal penegakan hukum dilakukan oleh OJK. Kewenangan OJK untuk melakukan penegakan hukum dapat dilihat dalam pasal 49 UUOJK. OJK dapat merekrut penyidik dari kepolisian dan ppns dari instansi lain karena secara kelembagaan, pegawai OJK tidak ada yang berstatus sebagai pns karena berada di luar Pemerintah, sehingga tidak menjadi bagian dari kekuasaan Pemerintah maka tidak ada Penyidik Pegawai Negeri Sipil (PPNS) di lingkungan OJK yang melakukan penyidikan. Sebagai penyidik dapat melakukan tindakan preventifdan represif dalam mencegah tippee mendapatkan informasi rahasia perusahaan dari insider dan menuntaskan kejahatan dibidang pasar modal yang dalam hal ini insider trading melalui bentuk pemeriksaan, penyidikan, dan penerapan sanksi dari

\footnotetext{
14 M. Irsan Nasarudin, op.cit, hlm.227
}

pelanggran dan kejahatan pasar modal. Oleh karena itu dengan adanya peraturan dan pengawasan yang memadai maka akan dapat mendorong investor untuk menanamkan modalnya dalam pasar modal. ${ }^{15}$

\section{PENUTUP \\ 4.1 Simpulan}

Simpulan dari pembahasan diatas ialah:

1. Tindakan tippee yang berkaitan dengan insider trading tersebut dapat dilakukan secara aktif dilakukan dengan berusaha melakukan perbuatan melawan hukum seperti mengancam, dan mencuri informasi insider yang sudah diatur dalam pasal 97 ayat 1 UUPM dan pasif dengan tidak berusaha melakukan perbuatan melawan hukum yang belum diatur dalam UUPM.

2. Penegakan hukumnya dilakukan OJK dengan merekrut penyidik dari kepolisian dan PPNS dari instansi lain karena secara kelembagaan, pegawai OJK tidak ada yang berstatus sebagai PNS karena berada di luar Pemerintah, sehingga tidak menjadi bagian dari kekuasaan Pemerintah maka tidak ada Penyidik Pegawai Negeri Sipil (PPNS) di lingkungan OJK yang melakukan penyidikan. Sebagai penyidik dapat melakukan tindakan preventif dengan melakukan pengawasan yang terhadap insider. Tindakan represif dengan melakukan pemeriksaan, penyidikan, dan penerapan sanksi kepada pelaku insider trading.

15 Pandji A. dan Piji P., 2003, Pengantar Pasar Modal, Rineka Cipta, Jakarta, hlm.97. 


\subsection{Saran}

Saran yang dapat diberikan berdasarkan simpulan diatas yaitu:

1. OJK dari awal hendaknya melakukan tindakan intensif dan preventif untuk mencegah terjadinya insider trading dengan melakukan pengawasan terhadap insider yang memberikan informasi rahasia perusahaan kepada tippee.

2. Hendaknya Peraturan perundang-undangan lebih menjangkau luas tindakan dari tippee yang pasif. Selain itu sanksi yang diterapkan di peraturan perundang-undangan ditingkatkan sehingga orang melakukan insider trading dapat dihukum dengan lebih berat.

\section{DAFTAR PUSTAKA}

\section{Buku:}

Hendrik Budi Untung, 2010, Hukum Investasi, Sinar Grafika, Jakarta.

H. Amiruddin dan Zainal A., 2008, Pengantar Metode Penelitian Hukum, PT. Raja Grafindo Persada, Jakarta.

H.L.A. Hart, 2013, Konsep hukum, cet, V, terjemahan M. Khozim, Nusa Media, Bandung.

Johnny Ibrahim, 2005, Teori \& Metodologi Penelitian Hukum Normatif, Bayumedia Publishing, Surabaya.

Jusuf Anwar, 2008, Penegakan Hukum dan Pengawasan Pasar Modal Indonesia, P.T Alumni, Bandung.

M. Irsan Nasarudin dan Indra S., 2004, $A s-$ pek Hukum Pasar Modal Indonesia, Kencana, Jakarta.
Syamsudin, M., 2007, Operasionalisasi Penelitian Hukum, PT. Raja Grafindo Persada, Jakarta.

Pandji A. dan Piji P., 2003, Pengantar Pasar Modal, Rineka Cipta, Jakarta.

Pedoman Penulisan Usulan Penelitian Tesis Dan Penulisan Tesis, 2013, Program Studi Magister Ilmu Hukum.

Peter Mahmud Marzuki, 2005, Penelitian Hukum, Prenada Media, Jakarta.

Sri Mamudji, Dkk, 2005,Metode Penelitian Dan Penulisan Hukum, Fakultas Hukum Universitas Indonesia, Jakarta.

Tavinayati dan Yulia Q., 2009, Hukum Pasar Modal Di Indonesia, Sinar Grafika, Jakarta.

\section{Jurnal}

Tandi P. Palayukan, 2013, Analisis Terhadap Larangan Praktik Insider Trading di Pasar Modal, Vol.II.

\section{Peraturan Perundang-undangan:}

UU No 8 tahun 1995 tentang Pasar Modal.

UU No 21 tahun 2011 tentang Otoritas Jasa Keuangan. 